\title{
HISTORICITY AND HUMANITY IN HEYDAR ALIYEV'S LITERARY AND THEORETICAL HERITAGE
}

Salatin Akhmedova ${ }^{1}$

Abstract: An analysis of the history of Azerbaijan's independent statehood indicates that such a difficult, complex and honorable mission as building a state could be led by a strong-willed person with a broad and global worldview, supported by the people and become their national leader. In the late 90 s of the XX century, the only leader who could claim this role in Azerbaijan and was able to cope with this work was Heydar Aliyev. An important part of the theoretical and practical activities of Heydar Aliyev is his doctrine of national statehood, a national-spiritual and ideological-political worldview. The study of its rich heritage in this area deserves to play the role of an example not only for current socio-political circles, but also for future generations, all the leaders who will lead Azerbaijan. The ideological world of this historical figure, laying the solid foundation of modern Azerbaijan, will always illuminate the path of his followers.
Keywords: Heydar Aliyev, Azerbaijan, Heritage, statehood

\section{Introduction}

The ideas and thoughts of Heydar Aliyev, his policy laid the scientific and theoretical foundations for the transition from a socialist socioeconomic system to a new society in Azerbaijan. For young Azerbaijan, freed from the imperial and socialist system and embarked on the path of independence, but faced with diverging, overlapping interests of regional and global forces, seeking its place in a globalizing world, striving to protect its interests, the doctrine of the statehood of Heydar Aliyev was a real strategy of activity. The practical activities and ideological and political views of Heydar Aliyev played a huge role in the return of the Azerbaijani people, who for many years were deprived of statehood and national-spiritual roots, whose national

Ph.D in Philology, Azerbaijan Architecture and Construction University,Azerbaijani Language And Literature Faculty,Azerbaijan, Baku, salatin.akhemedova@mail.ru 
and state interests were violated, to their origins, their self-affirmation. Heydar Aliyev (1923-2003) is a great personality brought up by the Azerbaijani people in the twentieth century, who created the history. He was a historical figure with a phenomenal memory, sagacious mind, and ability of highly eloquent speech, high political will, flexible logic, amazing historical vision, and divine talent. The great statesman Heydar Aliyev amazed everyone around with his high professionalism talking about agriculture, industry, science and culture, as well as literature. The whole world recognized Heydar Aliyev as a standard of personality and leader in last decade of the twentieth century. Academician Ramiz Mehdiyev writes: "The proper understanding of the role of personality in the history is not "an addition" to the understanding of the role of unity or other social forces. This role is a relatively independent element of history. The role of the individual is required for becoming an important aspect and driving force of the historical development. Personalities act as a driving force of social development at all stages of history. This means that, without exception, each personality is a driving force of history. Being a driving force of the historical development, in general, is an important humanistic quality of a person. As an individual, he is the essence and a driving force of history, and an active participant of the historical process.

To understand thoroughly and fully the complex mechanism of social life and driving forces of history the decisive role of the personality in history should be fully comprehended" (Mehdiyev R.,2001, pp. 31-32).

Political and cultural figures of the twentieth century, which was quite complicated, but at the same time very rich and contradictory, highly appreciated Heydar Aliyev in their works as a phenomenal personality. They believe that, his presence gave honor and glory to the nation, and glorified the name of Azerbaijan popularized all over the world with own talent and deeds. Academician Ramiz Mehdiyev says: "We have found numerous qualities characterizing the magnitude of the personality in the political and public activity of the Azerbaijani President Heydar Aliyev. As a historical figure, Heydar Aliyev is a founder and carrier of the eternal and immortal values, which are the fundamental base of the Azerbaijani 
state establishment and independent development. Analysis and understanding of Heydar Aliyev's long-term activity proves how robust and broad his intelligence and talent was, and how purposefully and enthusiastically he created the history of the Azerbaijani people” (Mehdiyev R.,2001, p. 44).

Indeed, all the features peculiar to leaders and historical figures are embodied in the personality of Heydar Aliyev. If we do not mention some specific aspects of the leader, we cannot give the true literary and historical values of his sayings about our great and ancient literature, classic word art, folklore, culture and art, and finally about our spiritual life. He loved his people and ruled them with hard realities dictated by the history. In particular, returning in 1993 (June 15), was succeeded to assemble and organize the people, who lost their way. In such circumstances, Heydar Aliyev consolidated the people and united them around a single idea. He showed the people the way to go through the history. He founded the science of ruling not only everyone, but everything. He directed the environment where the people gathered. It was a true leadership. Of course, the leader had a power, which affected mass psychology quickly and without resistance: it was literature and art. Taking into account the circumstances, he said: "Our country will surely face some difficulties when celebrating great anniversaries in this challenging period. However, the spiritual and cultural parts of our lives will never be forgotten. Despite of many challenges, we should always pay special attention to our culture, cultural heritage and spirituality, and never let these areas to lag behind. We have also to be very careful and cautious with our science, culture, and spirituality. This should not be given to the disposal of the market economy" (Heydar Aliyev, 1999, pp. 201 and 215). Literature and culture, as well as cultural politics occupied an important place in H.Aliyev's statehood conception. Later, he was capable to use the art and philosophical opportunities of literature and culture as a fundamental of national ideology, belief of independence - philosophy of Azerbaijanism. Thanks to his right and deliberate policy, taking into account the course of history, the $1300^{\text {th }}$ anniversary of "The Book of Dede Korkut" epos, the $500^{\text {th }}$ anniversary of the great poet M. Fuzuli were celebrated globally as the events of science, culture, word art, and mentality, 
and introduced not only Azerbaijan, but also Turkic community to the world.

Giving the value of his wise policy, Azerbaijani President Ilham Aliyev wrote in 2001: "The policy of the Azerbaijani leadership is the only correct policy. It is also proved by life. Azerbaijan has managed crisis with dignity. It has avoided the threat of civil war and the disintegration of society. At present, Azerbaijan is experiencing stability, strong economy, and much work is being done for the democratization. Therefore, I am absolutely sure that this policy should be pursued now. It is no doubt. The current policy should be followed for many decades. Otherwise, Azerbaijan may be exposed to any kind of anarchy" (Izvestia newspaper, May 19, 2001).

The concept of literaryhistorical process created by Heydar Aliyev was one of the main components of the culture of the Republic of Azerbaijan. The target of which was the Turkic world. The great thinker was stating on behalf of the Turkic goal when solving the most global problems, he was referring to it directly. The ideals of Turkism were standing as the bases for his attitudes to the literary history, separate literary personalities, literary stages and monuments.

\section{Research Aim}

When determining the position of epics, classic heritage, or literary and cultural works of the twentieth-century in the literary and cultural movement in a globalized world, H.Aliyev always stated from the Turkic context. His concept was a universal theory with deep historical background.The main purpose of the article is to investigate the works in the context of this concept.

\section{Research Methods}

The work uses system, structural and comparative methods of research, the method of hermeneutic analysis of the literary text.

\section{Development}

At the third Congress of Writers of the Turkic world (6 November 1996), in his speech he said: "The Turkicspeaking peoples have provided great contributions to the world culture and enriched it living in a large part of the ancient and centuries-old Eurasian continent. Throughout the life, the Turkic peoples have faced various wars, threats and violence, which sometimes 
threatened the existence of nations. However, the deep roots of our peoples and their moral commitment with one another have saved them at all stages, experiments, and brought to present days. We can be proud of our own historical and national roots and moral values." (Heydar Aliyev, 1999, p.338). Thus, three important factors of the spiritual and historical existence of the Turks - genetic unity, language unity and religious unity are capable of creating a single state. Moreover, this unity stands for the basis of Heydar Aliyev's attitude of nation, state, literature and culture. Among the main factors preserving the ancient history of the Turks and leading them to the future he paid a special attention to culture and literature.

The eposes reflecting the ancient Turkic history and spirituality "The Book of Dede Korkut", "Manas", "Algamish", "Koroghlu" and the great classics as Nizami, Ahmet Yasevi, Yunus Emre, Mevlana Jalaluddin Rumi, Alisher Navoi, Nasmi, Fuzuli, and Abay are of the literary monuments linking the Turkic peoples. The $1300^{\text {th }}$ anniversary of "The Book of Dede Korkut", $1000^{\text {th }}$ anniversary of "Manas", $500^{\text {th }}$ anniversary of Fuzuli have to be appreciated not only as literary, as well as social and historical events.

The purifying role of religion in society, the history of spirituality is invaluable. The last great religion of the world - Islam, which has deep philosophical roots and divine foundations, is a democratic religion elevating a human personality. Historically, "The Arabs have created the religion, and the Turks have immortalized the religion. All major Turkic marches have been realized under the banner of Islam" (Professor N.Shamsizadeh). The combination of Turkism with Islam is a great event of the civilization. The moral power of religious values was of great importance in H.Aliyev's literary-historical conception.

Heydar Aliyev has always paid great attention and love the mother language. Back in 1978, when the Soviet regime and its totalitarian ideology were dominating, the Azerbaijani language was included in the Constitution of Azerbaijan SSR by Heydar Aliyev's insistence as the official language. One of the problems, which was principally struggled for by H.Aliyev, was mother tongue. He viewed the fate of the mother tongue as the fate of the mother country. 
This tradition comes back from the twentieth century. The struggle for mother tongue led by U.Hajibayli, J.Mammadguluzadeh,F.Kocharli, N.Narimanov and A.Shaig has gradually turned into the struggle for the homeland, in fact, also served for both Turkism and Azerbaijanism ideologies.

H.Aliyev's language guidance was a system with its conceptual basis. He loved his nation, state, religion and language from the bottom of his heart and never separated them from one another: "Every nation's national identity, moral values, and culture is immortalized and developed by its language. Our language has always been immortalized, enriched and developed by poets and writers" (Heydar Aliyev, 1999, p.338). Aliyev repeatedly noted that in the East, as well as in Azerbaijan, the artists, writers, and poets have always been greatly respected. Therefore, "Azerbaijani Literature is a national wealth and intellectual property" (Heydar Aliyev, 1999, p.420).

Such high respect to the literature is a great quality for the state leader. It is an expression of deep love of the president for his people. Heydar Aliyev was well aware of the power of the literature and word art.
"There is a word that cuts the heads.

There is a word that stops the war".

- He said, skillfully using artistic and philosophical possibilities and the power of poetic influence of his political and moral father - Shah Ismayil Khatai. He needed the word not only as a means of literary and artistic heritage, but also as a means of influencing the national consciousness and awakens, power and energy storage, which does not depress the nation. His ides can prove our conclusions: "The greatest contribution of our literature to our people is that our poets and writers have always tried to evoke national feelings of our people and nation with their works. National identification, national revival, and the reinforcement process first of all come from the literature." In particular, from the late nineteenth century and early decades of the twentieth century, namely, from "Akinchi newspaper" (The Farmer) (1875), when the national media was established, until the period of half century, when Azerbaijan was occupied by the Bolsheviks, the literature has served to the national and spiritual awakening. During this period, tens of media bodies and the writers published 
here - J.Mammadguluzadeh, I.Gaspirali, A.Huseynzadeh, M.Shahtakhtli, M.ASabir, U.Hajibayli, A.Hagverdiyev, A.Aghaoghlu, M.A.Rasulzadeh and others were publishing in not only in "Molla Nasraddin", "Fuyuzat", “Tarjuman”, "Kaspi”, "Hayat”, "Shargi Rus", "Igbal" and others, but as well as in the world-famous magazines and newspapers, struggling for their ideology. The press has much sensitized the literature and formed its influence on the national consciousness. Characterizing this period, Heydar Aliyev said: "The twentieth-century was a period of intense, complicated and contradictory processes in the world history" . The great leader repeatedly stated that the Azerbaijani history of the nineteenth and twentieth centuries as well as the history of literature have not been sufficiently studied.

The key criterion of Heydar Aliyev's attitudes to the literary heritage and social processes was the historicity. The literature with no confidence in the historicity cannot be universal.

The historicity does not only describe the history, but also analyzes the modern era as a historical epoch. The historical experience is a theoretical and methodological criterion needed at all times. Heydar Aliyev approached both the classical heritage and modern literary process from this criterion - the experience of history. The events of the second half of the twentieth century took place before his eyes. He was both a participant and an organizer of them, in a word; he was the creator of the history. Thus, in Heydar Aliyev's theoretical views "the experience of history" was efficiently combined with "Heydar Aliyev's experience", which was exactly theoretical power of Heydar Aliyev's heritage. The historicity was in his manner of thinking. With the power of this historicity he was thinking in dialectical level, and was able to overcome the history and the time. This is confirmed by prominent researchers: "One point in Heydar Aliyev - The Time, Heydar Aliyev - The History relations attracts attention: the rivals of Heydar Aliyev's ideas existed every time and everywhere, but the biggest victory was achieved in the struggle with the time. 75 years - is the giant peak conquered over the time. And everything, especially the memory in this peak remained inviolable, sovereign and intact: during these 75 years a handful of memory could not be occupied" (Garayev Y.,1998, p.134). 
Heydar Aliyev was a historical figure, head of nation and state, changing the course of history and managing to recreate it. He raised our state to an unprecedented peak of history at a difficult historic moment, passing through public zigzags. Heydar Aliyev's speech was an example of a historical approach - the principle of attitude toward the history and literary pastime in his meetings with the writers. At the meeting of the State Commission on the $500^{\text {th }}$ anniversary of Fuzuli (1 August 1994) he said: "As we are all the children of time and period, we cannot go beyond its stereotypes. There was no opportunity to get out, because at that time writers, scholars, and even ordinary people believed that it cannot be otherwise. Therefore, no one can boast now. Such people then wrote so too. It is a reality of our history. It cannot be distorted. After 1917 some people tried to do something, but could not. Now, it is a sin to blame the people, who were developing the Azerbaijani culture and literature in that period" (Heydar Aliyev, 1999, p.206207). This logical view includes both historicity and a profound humanity. The fate and heritage of the creators, who lived during the Soviet period, cannot be viewed from the mechanical point of rejection, but from an objective history and sensibility. When it comes to the literature, on the one hand, the Soviet literature, which was serving to the Bolshevik and proletariat ideology, and the national Azerbaijani literature were establishing and developing. The prominent artists as M.Musfig, S.Vurghun, R.Rza, M.Ibrahimov, M.S.Ordubadi, and S.Rahimov preserved the traditions of our national literature. How can we review the creativity of A.Mammadkhanli, I.Afandiyev, I.Huseynov, B.Vahabzadeh, A.Karim, F.Goja, Kh.Rza, A.Salahzadeh, Y.Samadoghlu, Anar, Elchin, S.Ahmadli, R.Rovshan as the Soviet literature? No doubt, they were certainly influenced and pressed by the Soviet ideology. However, they were secretly resisting the ideology, creating the national literature. By the end of the twentieth century some of them died. B.Vahabzadeh, I.Afandiyev, I.Mughanna, I.Shikhli were preserving the national dignity of the Azerbaijani literature until the end of the century. Today, I.Mughanna is still working in this direction. Abovementioned poets and writers laid the cornerstone of the independence stage of the Azerbaijani literature in the last decade of the 
twentieth century. Heydar Aliyev gave valuable insight about each of these artists and, and presented literary and historical value of their creations: "We have also to be very careful and cautious with our science, culture, and spirituality. This should not be given to the disposal of the market economy" (Heydar Aliyev, 1999, p.216).

In that period, when our country took the first steps into capitalism, and everything became dependent on the market economy it was the great example of care to the spiritual heritage, a national culture, and at the same of the contribution to the.

A combination of the historicity and modernity is the cornerstone of Heydar Aliyev's literary and theoretical heritage. He was a symbol of the modern politician, statesman, thinker, and the latest leader. He never omitted anything and controlled everything in the period he lived and in the community surrounded by. H.Aliyev brought the past to modernity with great talent and skill, and combined its best practices with the interests of the Azerbaijani state. Modernity is not only the aesthetic category of Heydar Aliyev's instruction, but a manner of global thinking of the great historical figure. Modernity of
Heydar Aliyev's heritage was a worldclass. He was able to outline his mind, forecast the events. He demonstrated a true patriotism when making decisions of great importance for the national history being fully able to act decisively" (Heydar Aliyev and the Azerbaijani literature, 2010, p.1). As a thinker, H.Aliyev's way of thinking - was the way of history. He paid a special attention to the history of literature as to the way of historical development. Analyzing the history of literature as a mirror of national and social history, the national leader treated literature as a poetic source of ideas of spiritual culture in general: "Literature has brought great benefits to our people. We have to be proud of it. Personally, I have always thought so and I still think so, and will think so. I believe that our literature and poetry, the writers' words have the huge impact on the community, nation, and the people" (Mehdiyev Ramiz, 2001, v. p. 450). H.Aliyev skillfully used the opportunities of this effect, expressed both the people's psychology and social processes, as well as timely revealed and resolved vital national issues.

World-renowned classics as Khagani, Nizami, Nasimi, Fizuli ... are not only literary, but also historical and 
philosophical examples. In general, the literature is not limited with only reflecting the spiritual world and thinking history of people, but also enlightened the path of history. In most cases, the great personalities entered the history through literature and art of word. So did H.Aliyev. In the early days back in the power, he said: "Our culture and science are very rich. When we talk about Nizami and Fuzuli we mention them not only as the poets, but as the great philosophers and thinkers who had made great contributions to the world culture and science"(Heydar Aliyev,2002, p.201).

In the historic order on celebrating the $840^{\text {th }}$ anniversary of the great poet Nizami, he was presented as a great poet and the peak of Oriental Renaissance to the world. Due to H.Aliyev's personal and great effort and initiative, and the love of the people for the centuries-old literature, the public attention all over the world was directed toward the Nizami period, his life and creativity. The problem of Eastern Renaissance was expressed. In spite of resistance of some European and particularly Russian Soviet orientalists with Armenian traits, even in the 20s of the twentieth century, the problem of
Renaissance rose in the articles by Ali Nazim and M.Rafili became the subject o discussion. International symposium was held on this topic, and collected works and a monograph by Professor Arif Hajiyev in Russian "Nizami poetry and Renaissance" was published. As a far-sighted politician, H.Aliyev was a visionary thinker of the scientific and theoretical history of thinking. In 1981, when he was rebuked that the figure 840 was not anniversary, the great leader replied: "When we celebrated Nizami Ganjavi's $840^{\text {th }}$ anniversary as a great event we were reproved that 840 is not a round figure. However, we proved that Nizami Ganjavi was such a person that left a sign on the world culture so that it his anniversary may be held annually" (Heydar Aliyev,2002, p.200). In fact, after this official orders, Nizami creativity was in the center of attention in the context of those period, and the department of "Nizami study" was created at the Institute of Literature after Nizami of the Academy of Sciences under the leadership of outstanding orientalist and Nizami studier, Professor Rustam Aliyev. "Khamsa" by the great poet was studied and translated precisely in Russian in Moscow and published in Azerbaijani in Baku in numerous copies. 


\section{Discussion}

In terms of artistic and philosophical point of view, H.Aliyev started to be seriously interested in the heritage of incomparable classic yet in the early 70s. In this regard, his great attitude toward the Hurufism poet and philosopher Imadaddin Nasimi can be reviewed as the story of reviving Nasimi and struggling for recovering Nasimi's historical right. In the 90s, in the preparatory meeting dedicated to the celebration of the $500^{\text {th }}$ anniversary of Fuzuli he stated: "When I was in Syria in the 70s, I went to the city of Aleppo specifically to visit Nasimi's grave. Syrian President Hafez al-Assad gave special instruction on the organization of my visit. The leaders of Aleppo told me that I would visit the grave in the morning. The next day, I had to wait 3-4 hours as they did not know where Nasimi's grave was. Finally, they found a man who knew its location. Nasimi's tomb was in the common cemetery. His derivatives were also buried there. There were no any |gravestone monuments and so on. That was not a tradition there. Nevertheless, the tomb was in a very good condition, there were people who served it" (Heydar Aliyev,2002, p.227).
Nasimi is the first Azerbaijani poet whose $600^{\text {th }}$ anniversary in 1973 at Heydar Aliyev's initiative was celebrated worldwide by UNESCO. Within the framework of his anniversary events critical text of his works were published by Professor Jahangir Gahramanov in three volumes. Selected works of the great poet, collection of articles, the book of "Nasimi" by academician H.Araslı in several languages, and the book of "The poet of great ideals" by M.Guluzadeh were published. The People's poet Gabil composed the poem "Nasimi", and the People's writer I.Huseynov wrote the novel "Mahshar" (Judgment Day), and one of the best historical movies "Nasimi" was filmed based on the novel. I.Nasimi's $600^{\text {th }}$ anniversary was not an ordinary anniversary of the poet. This anniversary drew attention of the Azerbaijani Literature Society to one of the most spectacular literary and philosophical movements of the Middle Ages - Hurufism. Historical film "Nasimi" has also, introduced Nasimi, hurufism, its theorist and founder, the great philosopher Fazlullah Naimi to the public, and popularized among the people.

Two literary events in our new independence history - the $1300^{\text {th }}$ 
anniversary of "The Book of Dede Korkut" epos, and Fuzuli's 500th anniversary are the peaks of H.Aliyev's attitude to the classical heritage. In this context, the characteristic of his attitude to the classic masters of the twentieth century Mirza Jalil, U.Hajibayli, H.Cavid, J.Jabbarli and S.Vurghun also arises. H.Aliyev's literary-theoretical views throw the light on the fate of the spectacular literary history of 1300 years from "The Book of Dede Korkut": "The Book of Dede Korkut" is our mother book. Dede Korkut is our predecessor and ancestor. We are proud that, we have such a historical monument as "The Book of Dede Korkut", and that we have such an ancient ancestor as Dede Korkut."

"The Book of Dede Korkut" constantly called peoples and nations to the unity and peace... Even today, we need this recall of "The Book of Dede Korkut”.

"The Book of Dede Korkut" always invited peoples and nations to peace and reconciliation. Even today, our nation is faithful to these wisdoms of "The Book of Dede Korkut" "The Book of Dede Korkut" is a monument unifying great scientific, cultural and spiritual ideas (Heydar Aliyev and the
Azerbaijani culture,2008, p.218-219). In the period of independence, Heydar Aliyev needed this "main book" to unite all the Turks, to show the important role of Azerbaijan in the Turkic history. The level of thinking of the Azerbaijani Turks has never been reflected in the literary and artistic works as in "The Book of Dede Korkut”. It does not only reflect the heroic history and the victory of the Turks, but also the history of statehood and spiritual power - the monument of the authority. H.Aliyev also reviewed Fuzuli as a creative genius and a poet historically unifying the Turks in the twentieth century - the eve of the third millennium, and an event of Turkic thinking in the poetry: "Arabs and Persians consider Fuzuli their own poet. However, the Turkic peoples believe that he was a Turk. And we say Fuzuli is a Turk and Azerbaijani. It can also be said by the Turkmens, Uzbeks, Kazakhs, Turks living in Turkey, Iraq Turkmens. Let, Fuzuli belong to all of us, as a human personality in the history" (Heydar Aliyev, 2002, p. 221-222).

H.Aliyev did not consider these anniversaries as an ordinary campaign, but also gave great importance to their historical significance and prospects. We have to continue the study and promotion 
of Fuzuli even after the anniversary stated the national leader, which proved the national and historic status of the anniversary of the classic in his concept of the literary-historical processes: "Celebrating the anniversaries of historical figures, on the one hand, is giving the right value for their contributions and services to the people and to the nation. It is essential and indispensable. On the other hand, celebration of such anniversaries demonstrates the richness of the people and nation. At the same time, they help to raise the nation in the future" (Heydar Aliyev and the Azerbaijani culture, 2008,, p.343). Raise the people and the nation! - Is there any aim higher than that?! Of course, there is not! The idea of raising the people and the nation through literature, the power of word was the basis of H.Aliyev's theory of statehood and the national ideology of Azerbaijanism.

He highly appreciated the literary and political figures in the historical context of their period and required others to do so. During a meeting with intellectuals of Azerbaijan National Academy of Sciences on September 21, 1993, he expressed valuable ideas in this regard: "our history is very rich and the people should be aware of this... Exploring both the creativity of our great personalities, as well as their services for the Azerbaijani people has always been one of the important duties... Each personality has its place in the history... We do not need to distort the history... And we cannot lose our personalities... Nariman Narimanov was a prominent feature and a greater political figure of his time... Those who distort the history betray and confuse the people".

"All the personalities of our history are valuable for us. We cannot disturb them" (Heydar Aliyev, 1999, p.185-187). Thus, historicity as a methodological principle was the key point in H.Aliyev's theoretical and aesthetic criteria, which helped him to identify objective truths.

M.Fuzuli enters Heydar Aliyev's concept of literary-historical processes as a "great poet of all Turkic peoples", which is historically quite right value. He estimated him as "an example for the present and future of the Azerbaijani people, Turkic world and Turkic peoples" (Heydar Aliyev, 1999, p.217). Fuzuli study is a great science, "the history of which started with Fuzuli himself" (G.Aliyeva-Kangarli). In this 
regard, scientists from Azerbaijan, Turkey, Europe, the Middle East, and Russia... have written valuable monographs and books. Each of these publications has its own merits, research and historical role. However, Heydar Aliyev's attidute toward Fuzuli is more original and global in terms of scale. In his concept, Fuzuli is presented in terms of the Turkic world. In the middle ages, two giant artisans M.Fuzuli and A.Navai were source of belief and faith for the Turkic peoples." During his speech at the Turkish Grand National Assembly Heydar Aliyev said: "Fuzuli was a personality that combined the Turks in the past. But now, in the twentieth century, when the Turkic world has been split, Fuzuli is preserving us even though almost absolute majority (except Turkey) of countries belonging to the ancient Turkic world is experiencing the regimes that do not fit their lives, history, traditions and customs" (Heydar Aliyev, 1999, p.21).

One of the reasons of such great importance given to Fuzuli by H.Aliyev was uniting the Turkic world, and especially Turkic republics slit and scattered in the twentieth century. It was the wise aim of the great politician. $\mathrm{He}$ did not choose a direct political path to unite the Turkic nations, he chose the spiritual path; he preferred the path of "The Book of Dede Korkut" reflecting Turkish history and morality, the path of "Manas", and Fuzuli's creativity. A prudent politician and great strategist introduced Azerbaijan to the world through Fuzuli, showed the position of the Turks in the great world civilization, and demonstrated also the way of combining the Turks $\mathrm{t}$ the future generations. It was artistic and historical conclusion arisen from a combination of H.Aliyev's intelligence and Fuzuli's wisdom.

H.Aliyev brought up a new and optimal form literary legacy: the classical heritage is both the source of subject and ideas for new literary generations and poetic exemplar. For example, the writers and poets of the twentieth century repeatedly referred to the topics of Nizami and Fuzuli, searched for the answers to the questions of their age, and brought the literarypoetic freshness to these issues. Though, the revival of classics in the modern times has not always been the renaissance, it was possible in the world literary-historical processes. In fact, the power of classical literature, and its 
immortality and humanity is, first $\mathrm{f}$ all, in its poetic power.

As for Heydar Aliyev, the great poets as Fuzuli contributed to the progress of their peoples, becoming a kind of lighthouse for the promotion of the nation in the darkness of the history: "The Azerbaijani people have passed through hard stages. However, in all these difficulties, the great works by great creators and personalities of Azerbaijan helped the Azerbaijani people. Fuzuli occupies a prominent place among them" (Heydar Aliyev, 1999, p.221).

Fuzuli is an artistic and philosophical peak of the East-Azerbaijan literature of the Middle Ages. A combination of historicity and modernity defines the methodological basis of his approach to the classic heritage. In fact, it was an example of reading the classical heritage in the language of modernity. With respect to Fuzuli, Heydar Aliyev's intelligence and Fuzuli's brilliance complement each other in an organic way. Revealing the essence of Fuzuli's wisdom and showing it to all over the world was bestowed to Heydar Aliyev in the twentieth century more than anyone.

The twentieth century is wholly included into H.Aliyev's literary- historical concept - along with its sociohistorical contradictions and philosophical, scientific and artistic achievements. In this regard, Heydar Aliyev best acknowledged the twentieth century, analyzing it from the different parameters, metaphorically speaking, who was a mighty historical figure ruling twentieth century Azerbaijan from the end of the $60 \mathrm{~s}$. He analyzed the literature and culture of the twentieth century in a combination of the century itself: "The twentieth century is a very complex period for the entire world. In this case, Azerbaijan is not an exception, and especially because as a part of Russia, after the establishment of Soviet power, we experienced and adopted that structure, ideology, and social system. It is a history. Its each phase and each page are unique with its pros and cons" (Heydar Aliyev, 1999, p. 457). Of course, no nation can cut off its history and fate, whether it is bad or good. We can come to such conclusion that the twentieth century is a period of the great literature of Azerbaijan. Academician Mammad Jafar mentions in his threevolume book "Nineteenth century of the Russian literature" that the very rich Russian literature of the nineteenth century corresponds to the Azerbaijani 
literature of the twentieth century. There is a great truth in these words. Therefore, the twentieth century cannot be viewed as an ordinary period of literature and culture. From the literary-historical point of view, one of the characteristics of that politically scandal period was that the twentieth century remained loyal to its historical traditions and maintained them in the new historical conditions. It can be better observed in the first decade of the century - in an example of critical realism and romanticism. H.Aliyev particularly emphasized this point: "When we look at any century and any page of our history, we can see the tracks and works of poets, writers, and cultural figures. This is today's or yesterday's tradition, this tradition comes from centuries; this is respect and great honor to poems, poets, word masters, and intelligent people".

Being satisfied, we can say that in the twentieth century, which was full of very complex and contradictory processes, huge changes, wars and tragedies, this beautiful tradition tribute not only maintained, but even developed. Consequently, the Azerbaijani literature, poets and writers are respected" (Heydar Aliyev, 1999,p.413). The idea is a truth that characterizes our literary-historical process. H.Aliyev confirmed his own concept, referring to the popular words by S.Vurghun, "We have poetry and art, as well as respect for the poets, poetry and art". He highly appreciated of the wisdoms of the poet as the fact reflecting the literary-historical process taken place in Azerbaijan and artistic and philosophical traditions these processes.

H.Aliyev regarded late nineteenth and early twentieth century's as a period of abundant literature. He explained historically the reason for this and showed that the writers and poets living in this era brought the European literary and cultural experiences $t$ Azerbaijan remaining loyal to their Islamic origins: "In the nineteenth and twentieth century's, the Azerbaijani people did not stay apart from their national roots but managed to combine their literature and culture with the developed Western literature and culture" (Heydar Aliyev, 1999, p.420). H.Aliyev considered intellectuals carrying out this literary and history mission as "very far-sighted and wise" people. He also evaluated the creation of the National Theatre (1873) and the first opera (1908) as a great historical event.

H.Aliyev's interesting choices associated with literary figures of the 
twentieth century draw attention. Referring to the outstanding figures of the first decade of the century, he says: "We are proud of the literary personalities of the twentieth century such as Sabir and J.Mammadguluzadeh. In general, the twentieth century was very difficult period from the beginning until the end. It is true that, this scandalous century had calm periods, as well, however, with confused, difficult, and hard times" (Heydar Aliyev, 1999, p.399).

H.Aliyev particularly distinguished Sabir, Mirza Jalil, Jafar Jabbarli and Huseyn Javid in early twentieth century, honored. Referring to the Soviet-era poets, he said: "Samad Vurghun, Rasul Rza, and Suleyman Rustam entered the history of our literature as one of the founders of the Azerbaijani Soviet poetry" (2, p.159). Thus, in fact, in H.Aliyev's concept of literary-historical processes, the scope of twentieth-century literature is determined.

H.Aliyev often used an idea in his analysis methodology and aesthetic value criteria: evaluating the artist in the context of his period. He evaluated both Jalil Mammadguluzadeh and S.Vurghun in accordance with the time they live in.
For example: "Of course, Samad Vurghun's works are written accordance with his time. The requirements of that period are reflected in Samad Vurghun's works" (Heydar Aliyev, 1999, p.363364).

Such evaluation method brought historicity to H.Aliyev's views and provides the logical curse of his ideas. It is also proved in his attitude to the literary-historical processes of the twentieth century, as well as to the creativity of the personalities of previous century. There is also another noteworthy aspect of H.Aliyev's analyzing practice: to shift from the historicity to modernity, in other words, to achieve the unity of historicity with modernity. Evaluating Mirza Jalil, he says: "Mirza Jalil is a man of genius, writer, publicists, philosopher, thinker, and a person who enriched our culture and occupied a prominent place in the history of Azerbaijan. He is a classic of our literature and culture. At the same time, he is our contemporary, even today, he is within us...

With his creativity, works, publications, and journalism activity, J.Mammadguluzadeh played an essential role in the national awakening and revival. Invaluable role of "Molla 
Nasraddin” magazine and Mirza Jalil's activities in the formation of national consciousness is indispensable" (Heydar Aliyev, 1999, pp.240-241). Emphasizing the Mirza Jalil's ultimate merits and the role of "Molla Nasraddin" magazine in the formation of national consciousness in the illiterate country, H.Aliyev especially mentioned the pictures of the magazine, and its clear, simple and understandable mother tongue. The painters highly appreciated the paintings and cartoons of the magazine by Shmerling, Rotter, Azim Azimzadeh, and called them "a means of conveying unreadable ideas". The price given to U.Hajibayli can be regarded as a definite example of the historical attitude toward the artist: "All the personalities in our history are very valuable for us. We cannot forget any of them. Let's take the great composer Uzeyir Hajibayov. He is a founder of classical music and opera in Azerbaijan in the beginning of the century, a member of Musavat Party, and an author of the national anthem of the Democratic Republic of Azerbaijan. He enriched the culture of Azerbaijan in the Soviet period, creating "Koroghlu" opera and other works in the following years. Shall we distinguish two Uzeyir Hajibayovs? Or shall we distinguish his activity within Musavat Party and the Soviet period? We cannot! Uzeyir Hajibayov is too valuable personality. We cannot blame him, for that he met with Stalin with great pride in Moscow in 1938, and Kalinin presented him the Lenin Order" (Heydar Aliyev, 1999, p.187).

Such a model of attitude to the classical heritage, particularly to the complicated, controversial artists of the twentieth century has an objective scientific and historical nature.

There is a quite interesting idea in H.Aliyev's speech on the occasion of U.Hajibayov's anniversary not only about Hajibayov himself and twentiethcentury classics, but also about literary and historical figures in general: "No matter what the government is, the person faithfully serving to the people and their promotion should go forward" (Heydar Aliyev, 1999, p.295). U.Hajibayli was one of such literary and historical figures. Thus, H.Aliyev preferred the talented and creative personalities to all authorities, the public pressure, and confirmed the divine might of the great masters. As in social and political life, Heydar Aliyev was a steadfast and uncompromising man in regard with the literary and cultural 
personalities and the creative processes.

The talent and personality were a key criterion for him.

H.Aliyev noted some features raising U.Hajibayli to the "pioneered coryphaeus of the world": 1 . the founder of the national classical music and first national opera; 2. Synthesizing Eastern and European values in the music art; 3 . Relying on history and inspiring the national memory, and; 4. Establishing national musical school for composers after himself.

Heydar Aliyev's sayings about the prominent figure of the twentieth century romanticism, romantic poet and philosopher H.Javid define the methodological fundamentals of modern Javid study: "Huseyn Javid contributed to the development of twentieth century literature and culture. Huseyn Javid is one of the great personalities, who promoted the Azerbaijani people, its culture, literature and science. Huseyn Javid's works are national wealth of Azerbaijani people. They are manual books for the present and future generations. Huseyn Javid's all creativity and activity included the promotion of the culture of the Azerbaijani people, its freedom and independence. His whole activity of the raised the Azerbaijani people to the national sovereignty and liberty. $\mathrm{He}$ always lived with this will, and was loyal to his will and the nation, and extremely loved them, serving to them" (Huseyn Javid ,2008, p. 3).

Obviously, this conceptual value given to Javid's literary and historical position reflects a number of features characterizing the creativity of the great romantic poet and philosopher: he promotes our literature and culture; his works are our national treasure; his works teaches the present and future; his ideas are serving to freedom and independence; he demonstrated great creativity will; he was faithful to the nation and loved and served to them.

All of this endorses Huseyn Javid's personality as a romantic poet and philosopher, and reflects the national-historic and artisticphilosophical importance of his phenomenon. Heydar Aliyev's statements about H.Javid allow us to deeply penetrate his creativity. First of all, H.Javid was a romantic poet, who admired not existing things, but the things that should be in life.

"I am a poet of fascination

Cannot reach the ground, I am a poet of heaven" - 
Wrote H.Javid, who stood much higher than the terrestrial realities. Romantic pathos, unlimited flight of fantasy, the efforts for the absolute truth are the chief points describing his literary and artistic plight.

H.Javid, U.Hajibayli, J.Jabbarli and Samad Vurghun with his extraordinary talent and personality stand the highest points of the literary and historical processes of the twentieth century. S.Vurghun is the great figures of not only the Azerbaijani poetry and Soviet literature, but also of the world literature. Therefore, his heritage and personality occupies the main positions in Heydar Aliyev's school of literaryhistorical processes. Among the poets of the twentieth century H.Aliyev loved M.Shahriyar and S.Vurghun. He always moved into tears when saying the poem "Azerbaijan" by S.Vurghun. I believe that Heydar Aliyev's national ideology the national philosophy of Azerbaijanism is based on this poem.

H.Aliyev evaluated S.Vurghun in the context of world poetry. One of his considerations says: "In the twentieth century S.Vurghun's services for our culture, literature, social and political life is quite huge, and therefore people loved him alive, and worshiped him. Today, in independent Azerbaijan, in the time of national freedom and liberty, Samad Vurghun's works are extremely valuable especially for current and future generations" (Huseyn Javid ,2008, p.302-303).

The talent is the most precious gift given to a man by the God; it should be protected and respected. S.Vurghun's talent is a special aesthetic category. To reveal artistic and philosophical essence of his poetry, it is first necessary to analyze his talent. Poetic horizons of this talent were exceptionally wide. It had neither geographic, nor aesthetic boundary. S.Vurghun's talent was an aesthetic category. Analyzing the talent itself from the philosophical and psychological point of view is one of the aesthetic problems facing the modern theoretical ideas. H.Aliyev wrote: "Samad Vurghun's creativity is an immense, and so far all the writings have not been able to reflect all of it" (Heydar Aliyev, 1999,p.360). H.Aliyev always regarded all the great artists, and those who turned his talent into the national wealth and universal heritage through his works, in the context of the ancient Eastern traditions: "Samad Vurghun is a great poet. A poet was always worthy of great respect in the East. Samad Vurghun 
was one of the great poets of his time. Samad Vurghun brought great innovations in the Azerbaijani poetry..." (Heydar Aliyev, 1999, p.360)

These innovations are numerous: Samad Vurghun created a new system o artistic expression and a new poetics. The greatest innovation brought into the Azerbaijani poetry by the poet was the maximum approximation of the language of poetry to the language of people. Attitudes to the language according to Heydar Aliyev is a mastery criteria of a poet: "Samad Vurghun's poem enriched and developed the Azerbaijani language, making it native, lovely and sweet for every Azerbaijani people. It is one of the greatest services rendered to the Azerbaijani people by Samad Vurghun". Supremacy, and at the same time, the beauty of Samad Vurghun's poetry was that his every word and every line reached the heart of every Azerbaijani people, conquered his brain, and affected them" (Huseyn Javid ,2008, p. 361).

\section{Conclusion}

We believe that the Azerbaijani literary language was promoted to the

highest peak by the genius Fuzuli in the sixteenth century, by M.P.Vagif in the eighteenth century, and by Samad Vurghun in the twentieth century. Being innovative event for their own periods, these language revolutions are supposed to be perfected by Samad Vurghun's creativity. History has never been brought up to verse drama in such a simplified way rather than by Samad Vurghun. In general, it should be noted that founded by the great romantic poet H.Javid, historical drama in verse - is perfected by verse drama "Vagif".

The essence of the humanity of Heydar Aliyev's literary-theoretical heritage evolutes from the historicity and millennium. The nationality of literature is explained in the context of Azerbaijanism and Turkism. When determining the position of epics, classic heritage, or literary and cultural works of the twentieth-century in the literary and cultural movement in a globalized world, H.Aliyev always stated from the Turkic context. Therefore, his concept was a universal theory with deep historical background.

\section{References}


Mehdiyev R.(2001). Azerbaijan: historical heritage and the philosophy of modernity. Baku Heydar Aliyev.(1999). Duty and idea of literature. Baku, "Ozan", "Izvestiya" newspaper, May 19, 2001

Heydar Aliyev and the Azerbaijani literature. Baku, 2010

Heydar Aliyev.(2002). Our independence is eternal. Baku, Azernashr,

Heydar Aliyev and the Azerbaijani culture, III vol., Baku, 2008 Izvestia newspaper, May 19, 2001

Garayev Y.(1998). National Leader of the Independence period Heydar Aliyev and the Azerbaijani literature. Baku, Elm Huseyn Javid: life and occupation.(2005). Baku, Elm 